\title{
Karakteristik Penduduk Miskin di Papua Barat
}

\author{
Ludia Theresia Wambrauw ${ }^{1}$, Ratna M. H. Gusti ${ }^{2}$, Agus Irianto Sumule ${ }^{1}$ \\ ${ }^{1}$ Dosen Fakultas Pertanian, Universitas Papua \\ ${ }^{2}$ Staf Badan Pusat Statistik
}

Permalink/DOI: http://dx.doi.org/10.32830/jfres.v1i1.1025.g768

Received: April 2018; Accepted: June 2018; Published: September 2018

\begin{abstract}
Abstrak
Penelitian ini berjudul Karakteristik Penduduk Miskin di provinsi Papua Barat. Tujuan dari penelitian ini adalah untuk mendeskripsikan karakteristik penduduk miskin, dan untuk menganalisis beberapa faktor yang mempengaruhi kemiskinan di provinsi Papua Barat. Penelitian ini dilakukan di provinsi Papua Barat dengan menggunakan data dari Badan Pusat Statistik (BPS) Indonesia. Metode analisis deskriptif digunakan untuk memberikan gambaran karakteristik rumah tangga miskin di Papua Barat dan faktor-faktor yang mempengaruhinya. Hasil penelitian menunjukkan bahwa persentase penduduk miskin di Papua Barat mengalami penurunan dari tahun 2009 hingga 2016. Penurunan persentase penduduk miskin lebih banyak terjadi di wilayah pedesaan dibandingkan dengan wilayah perkotaan. Hasil penelitian ini juga menyatakan beberapa karakteristik rumah tangga miskin antara lain: jumlah anggota rumah tangga lebih dari empat orang; mempunyai tingkat pendidikan rendah; mayoritas hidup di daerah terisolasi dan bekerja pada sektor pertanian; tingkat migrasi rendah; dan tidak mempunyai gangguan kesehatan. Berdasarkan karakteristik-karakteristik tersebut, pemerintah Papua Barat seharusnya memberikan perhatian lebih terhadap pengembangan sektor pertanian dan meningkatkan infrastruktur sosial dan ekonomi di wilayah-wilayah pedesaan.
\end{abstract}

Kata kunci: penduduk miskin, Papua Barat

\begin{abstract}
This research entitles Characteristics of Poor People in Papua Barat Province. The research aims are to describe poor people characteristics in Papua Barat, and to analyze some factors that influence poverty in Papua Barat Province. The research is conducted in Papua Barat Province by using data from Indonesia's Statistics. Then a descriptive analysis method is used to describe the characteristics of poor households in Papua Barat and their contributing factors. The results showed that the percentage of poor people in Papua Barat has been decreasing from 2009 to 2016. The percentage of poverty is decreasing more in rural areas than in urban areas. The characteristics of the poor people are the number of household member is more than four people; have low level of education, majority live in remote areas and work in agricultural sector, less of them are migrants, and have no health issues. Based on those characteristics, the Papua Barat government should put attention in developing the agricultural sector and improving the social and economic infrastructures in rural areas.
\end{abstract}

Keywords: poor people, Papua Barat

How to Cite: Wambrauw, L.T., Gusti, R.M.H., Sumule, A.I. (2018). Karakteristik Penduduk Miskin di Papua Barat. JFRES: Journal of Fiscal and Regional Economy Studies, 1 (1), 69-76.

doi: http://dx.doi.org/10.32830/jfres.v1i1.1025.g768 


\section{PENDAHULUAN}

\section{Latar Belakang}

Masalah kemiskinan merupakan salah satu persoalan mendasar yang menjadi pusat perhatian pemerintah di negara manapun, termasuk Indonesia. Perserikatan Bangsa-Bangsa (PBB) pada September 2000 dengan 189 anggota mendeklarasikan pembangunan milineum (Millenium Development Goals/MDGs). Kemiskinan merupakan ketidak mampuan seseorang untuk memenuhi kebutuhan hidupnya. Badan Perencanaan Pembangunan Nasional (Bapennas, 2004) mendefinisikan kemiskinan sebagai kondisi dimana seseorang atau sekelompok orang laki-laki dan perempuan, tidak mampu memenuhi hak-hak daasar untuk mempertahankan dan mengembangkan kehidupan bermartabat.

Komitmen dari pembangunan milineum ini adalah bahwa pembangunan berpihak kepada pemenuhan hak-hak dasar manusia yang mengarah kepada peningkatan kualitas hidup. Indikator yang digunakan dalam upaya meningkatkan kualitas hidup pada tahun 2015 salah satunya adalah menanggulangi kemiskinan dan kelaparan.

Indonesia merupakan salah satu negara dengan jumlah penduduk miskin yang cukup besar yaitu 27,77 juta jiwa atau sekitar 10,83 persen pada tahun 2017 (BPS, 2018). Angka ini sudah menurun cukup tajam dari 2008 dengan jumlah penduduk miskin 34,96 juta jiwa atau 15,43 persen dari keseluruhan total populasi Indonesia. Walaupun sejak tahun 2008 sampai dengan 2017 terjadi trend penurunan kemiskinan, akan tetapi pada tahun 2015, terjadi kenaikan angka kemiskinan sebesar angka kemiskinan sebasar 0,2 persen dari tahun 2014, yaitu dari 10,96 menjadi 11,16 .

Penanggulangan kemiskinan bukan hanya menjadi tugas pemerintah pusat karena pada dasarnya masalah kemiskinan yang dialami setiap daerah berbeda (Kemal, 2012). Setiap negara memiliki karakteristik kemiskinannya masing-masing yang dapat diakibatkan oleh begitu banyak faktor seperti geografis, kultur, sistem pemerintahan, dan lainnya. Dikarenakan begitu kompleksnya permasalahan kemiskinan maka penanganan yang dilakukan hendaknya berbeda dan dilihat dari berbagai aspek pula.

Papua Barat merupakan salah satu provinsi dengan angka kemiskinan tertinggi. Jumlah penduduk yang berada di bawah garis kemiskinan di Papua Barat pada Maret 2016 sebesar 225,80 ribu jiwa (25.43 persen). Kemudian angka ini mengalami penurunan pada September 2016 menjadi 223,60 ribu jiwa (24.88 persen) atau menurun sebesar sebesar 0,55 poin (Tabel 1). Secara umum, jumlah dan persentase penduduk miskin di Provinsi Papua Barat mengalami penurunan selama periode tahun 2009-2016.

Upaya pemerintah yang selama ini dilakukan untuk menanggulangi tingginya jumlah penduduk miskin semestinya dilakukan dengan memperhatikan penyerapan tenaga kerja terbanyak seperti pada sektor pertanian, sektor industri, sektor jasa-jasa maupun sektor lainnya. Selain itu, perlu memperhatikan wilayahnya yaitu wilayah perkotaan atau perdesaan, sehingga

Tabel 1. Jumlah dan persentase penduduk miskin di provinsi Papua Barat tahun 2009-2016

\begin{tabular}{ccccccc}
\hline \multirow{2}{*}{ Tahun } & \multicolumn{3}{c}{ Jumlah Penduduk Miskin (000 jiwa) } & \multicolumn{3}{c}{ Persentase Penduduk Miskin (\%) } \\
\cline { 2 - 7 } & Kota & Desa & Kota + Desa & Kota & Desa & Kota + Desa \\
\hline 2009 & 8,55 & 248,29 & 256,84 & 5,22 & 44,71 & 35,71 \\
2010 & 9,59 & 246,66 & 256,25 & 5,73 & 43,48 & 34,88 \\
2011 & 10,78 & 239,06 & 249,84 & 6,05 & 39,56 & 31,92 \\
2012 & 13,27 & 209,97 & 223,24 & 5,36 & 36,33 & 28,20 \\
2013 & 14,21 & 210,06 & 224,27 & 5,65 & 35,64 & 26,67 \\
2014 & 14,06 & 211,40 & 225,46 & 5,52 & 35,01 & 26,26 \\
2015 & 18,82 & 206,72 & 225,54 & 5,68 & 37,94 & 25,73 \\
2016 & 20,11 & 203,49 & 223,60 & 5,69 & 37,33 & 24,88 \\
\hline
\end{tabular}

Sumber : BPS ,2014, 2017 dan 2018 
dapat mengidentifikasi informasi faktor-faktor penyebab kemiskinan seseorang atau sekelompok itu sendiri.

Berdasarkan uraian di atas, maka penelitian ini bertujuan untuk 1) mengetahui karakteristik rumah tangga miskin di Papua Barat, dan 2) menganalisis faktor-faktor yang mempengaruhi kemiskinan rumah tangga khususnya yang ada di wilayah pedesaan di Papua Barat.

\section{Tinjauan Pustaka}

Pengertian kemiskinan dalam arti luas adalah keterbatasan yang disandang oleh seseorang, sebuah keluarga, sebuah komunitas, atau bahkan sebuah negara yang menyebabkan ketidaknyamanan dalam kehidupan, terancamnya penegakan hak dan keadilan, terancamnya posisi tawar (bargaining) dalam pergaulan dunia, hilangnya generasi, serta suramnya masa depan bangsa dan negara. World Bank menyatakan bahwasanya penyebab dari adanya kemiskinan berada pada beberapa akses individu terhadap jumlah aset yang penting, yakni aset dasar kehidupan, aset alam, aset fisik, aset keuangan dan aset sosial.

Rumbewas (2005) menyebutkan bahwa penyebab dari seseorang dikategorikan miskin dikarenakan, tidak bekerja, tidak ada usaha, tidak punya keterampilan, dan ini berdampak kepada tidak adanya uang belanja, bentrok dalam keluarga, tidak dapat berobat, tidak mempunyai rumah. Selanjutnya menurut Widodo (2006) terdapat beberapa faktor yang menyebabkan rumah tangga atau seseorang dikatakan miskin yaitu: 1) rendahnya taraf pendidikan, 2) rendahnya derajat kesehatan, 3) terbatasnya lapangan kerja, dan 4) kondisi terisolasi. Kuncoro (2006) menganalisis penyebab kemiskinan dari dua faktor, yaitu faktor ekonomi dan faktor sosial. Faktor ekonomi ditunjukkan oleh (1) rendahnya akses terhadap lapangan kerja dan (2) rendahnya akses terhadap faktor produksi seperti modal usaha, akses pasar serta sedikitnya kepemilikan asset. Sedangkan faktor sosial ditunjukkan dengan rendahnya akses terhadap fasilitas pendidikan dan fasilitas kesehatan. Selanjutnya menurut Tulus (1997) ada sepuluh faktor yang menyebabkan kemiskinan di Indonesia dan kesemuanya itu saling mempengaruhi sehingga sulit memastikan penyebab kemiskinan yang paling utama atau faktor yang berpengaruh langsung maupun tidak langsung. Kesemua faktor tersebut merupakan vicious circle (lingkaran setan) dalam masalah timbulnya kemiskinan yaitu :

1. Tingkat pendidikan yang rendah

2. Produktivitas tenaga kerja rendah

3. Tingkat upah yang rendah

4. Distribusi pendapatan yang timpang

5. Kesempatan kerja yang kurang

6. Kualitas sumberdaya alam masih rendah

7. Penggunaan teknologi masih kurang

8. Etos kerja dan motivasi pekerja yang rendah

9. Kultur/budaya (tradisi)

10. Politik yang belum stabil

\section{METODE PENELITIAN}

Penelitian ini merupakan hasil penelitian deskriptif berupa review literatur. Penelitian ini mempergunakan atau memanfaatkan data sekunder, yaitu data yang sudah ada. Dalam hal ini peneliti tidak mengumpukan data sendiri, baik dengan wawancara, penyebaran angket atau daftar isian, melakukan tes, menggunakan skala penilaian atau skala semacam skala likert, ataupun observasi.

Data yang digunakan dalam penelitian ini adalah data sekunder hasil sensus penduduk yang terakhir dilakukan pada tahun 2013 dan laporan publikasi BPS baik nasional maupun Provinsi. Variabel-variabel yang digunakan diambil dari Survei Sosial Ekonomi Nasional (Susenas) tahun 2013. Data kemudian dianalisis dengan menggunakan metode analisis deskripstif untuk menggambarkan karateristik rumah tangga miskin di Papua Barat dan faktor-faktor penyebabnya.

\section{HASIL DAN PEMBAHASAN}

\section{Karakteristik Rumah Tangga Miskin di Papua Barat}

Hammar dan Saptomo (2008) mendeskripsikan orang miskin di Papua Barat sebagai berikut: (1) orang miskin adalah orang yang SDM nya rendah yaitu tidak memiliki keterampilan hidup (life skill), berpendidikan rendah dan terbela- 
kang; (2) tinggal di pinggiran kota dan kampung-kampung; (3) jumlahnya tiga perempat dari jumlah penduduk Papua Barat; (4) dikatakan miskin karena kesenjangan ekonomi antar wilayah; akses untuk mencapai pusat pemerintahan dan perekonomian; (5) pandangan orang miskin tersebut bahwa sesungguhnya tidak miskin tapi kurang diperhatikan, kurang diberdayakan. Selanjutnya untuk memberikan gambaran karakteristik rumah tangga miskin di Propinsi Papua Barat digunakan data Susenas tahun 2013 dengan jumlah rumah tangga sebanyak 15.947 (Tabel 2).

Tabel 2. Jumlah Rumah Tangga Hasil Sensus Nasional Tahun 2013

\begin{tabular}{clc}
\hline No & \multicolumn{1}{c}{$\begin{array}{c}\text { Kabupaten/ } \\
\text { Kota }\end{array}$} & $\begin{array}{c}\text { Jumlah } \\
\text { Rumah Tangga }\end{array}$ \\
\hline 1 & Fakfak & 1.725 \\
2 & Kaimana & 1.369 \\
3 & Bintuni & 1.573 \\
4 & Teluk Wondama & 1.137 \\
5 & Manokwari & 2.117 \\
6 & Sorong Selatan & 966 \\
7 & Kota Sorong & 2.006 \\
8 & Maybrat & 986 \\
9 & Sorong & 1.638 \\
10 & Tambrauw & 966 \\
11 & Raja Ampat & 1.211 \\
\hline
\end{tabular}

Sumber: Susenas 2013

Berdasarkan data yang ada di BPS Provinsi Papua Barat, maka diperoleh beberapa karakteristik dari penduduk miskin di Papua Barat.

\section{Jumlah anggota rumah tangga}

Keluarga dengan jumlah anggota rumah tangga yang lebih besar, berisiko lebih tinggi untuk menjadi miskin dibandingkan dengan rumah tangga dengan jumlah anggota rumah tangga yang lebih sedikit. Rumah tangga miskin di Papua Barat memiliki jumlah anggota rumah tangga lebih dari 4 orang. Dari Gambar 1 terlihat bahwa 30,7 persen rumah tangga miskin memiliki anggota rumah tangga lebih dari empat orang, sementara hanya 7.4 persen yang rumah tangga miskin yang memiliki anak kurang dari empat orang. Hal ini berarti jumlah rumah tangga miskin dengan anggota keluarga lebih dari 4 hampir empat kali lebih banyak dari rumah tangga dengan anggota yang kurang dari 4.

Gambar 1.a) juga menunjukkan bahwa anggota rumah tangga tidak miskin jauh lebih banyak yang memiliki anggota keluarga kurang dari 4, demikian juga yang lebih dari 4. Banyaknya anggota rumah tangga akan mempengaruhi kualitas kesehatan dan pendidikan yang terima, khususnya untuk anak-anak. Dalam hal kesehatan, pemenuhan gizi makanan anak-anak miskin cenderung kurang karena harus berbagi dengan anak-anak lainnya.

\section{Migrasi Risen}

Sebanyak 69.732 jiwa (atau 10,5\%) di Papua Barat merupakan migran risen dengan komposisi terbesar di area kota (13,1\% versus 9,3\%) dan mayoritas adalah migran laki-laki (40.348 versus 29.384).

Penduduk yang melakukan migrasi risen di Papua Barat lebih sedikit persentase kemiskinannya yaitu 76,79 persen, dibandingkan dengan penduduk yang tidak melakukan migrasi sebesar 78,56 persen (Gambar 1.b).

Pulau yang terus-menerus diserbu migran adalah Papua dan Papua Barat. Pada tahun 2010 sampai 2015, telah masuk sekitar 20 ribu perantau ke Papua Barat (https://tumoutounews.com/2017/ 10/19/data-migrasi-penduduk-di-indonesiamenurut-provinsi/). Kenaikan jumlah perantau ini, apalagi yang tidak memiliki keahlian atau pendidikan yang mencukupi memberikan pengaruh terhadap meningkatnya angkatan pengangguran di Papua Barat.

\section{Migrasi life time}

Jumlah migran seumur hidup di Papua Barat adalah 291.233 jiwa. Komposisi migrant life time di Papua Barat sebesar 52,3\% migran memilih kota dan hanya 32,3\% migran seumur hidup di daerah desa. Jumlah migran life time berjenis kelamin laki-laki juga lebih besar dibanding perempuan masing-masing 337.577 jiwa dan 130.483 jiwa (Putra, 2016). 


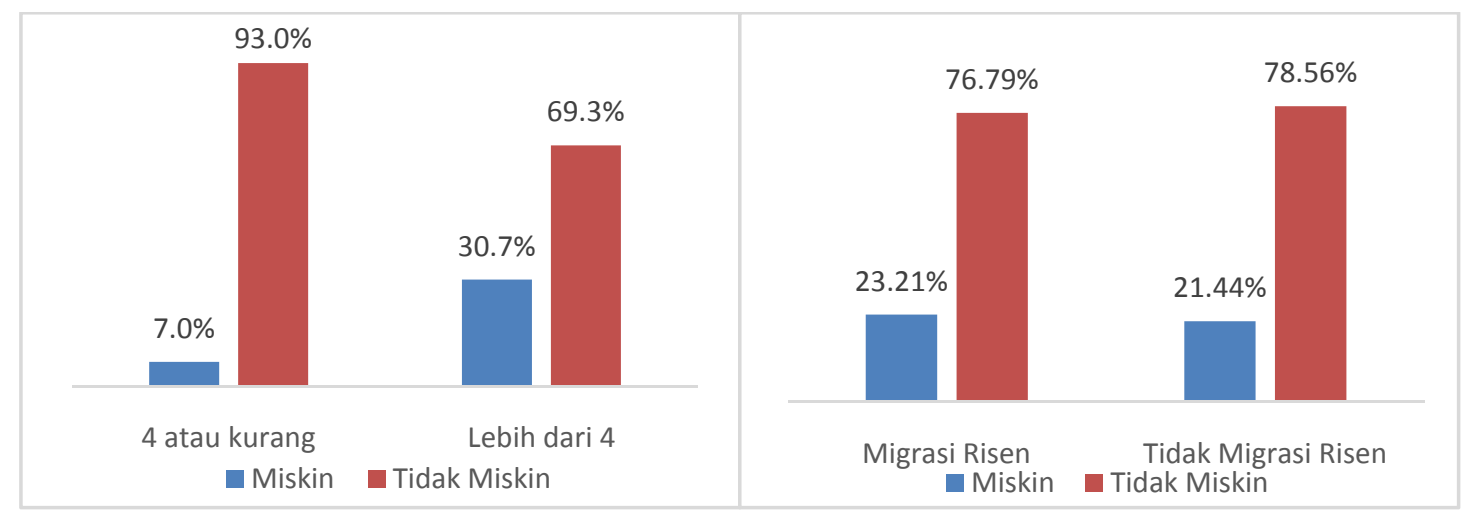

a) Jumlah Anggota Rumah Tangga

b) Jumlah Migrasi Risen

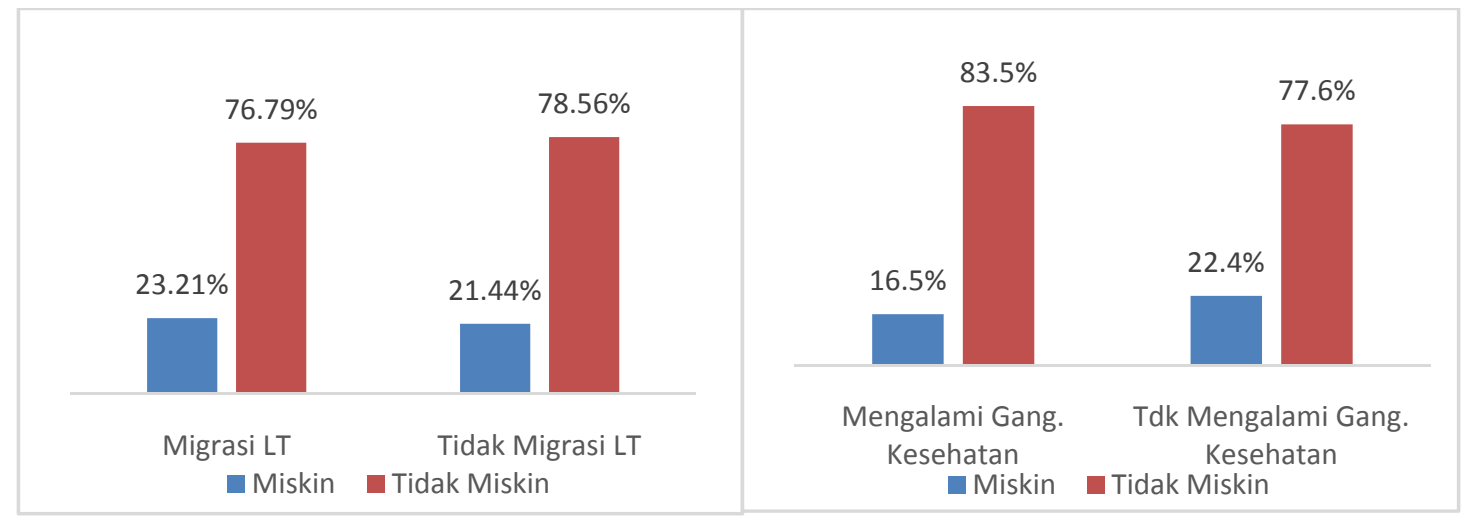

c) Jumlah Migrasi Life Time

d) Jumlah Gangguan Kesehatan

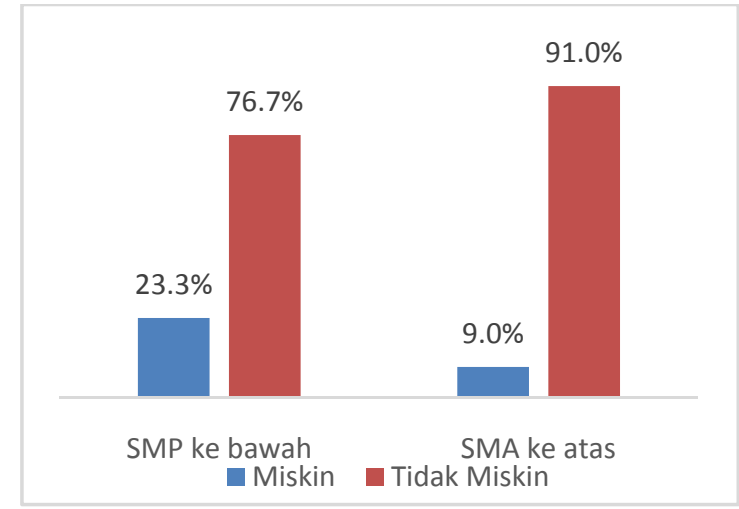

e) Pendidikan Kepala Rumah Tangga

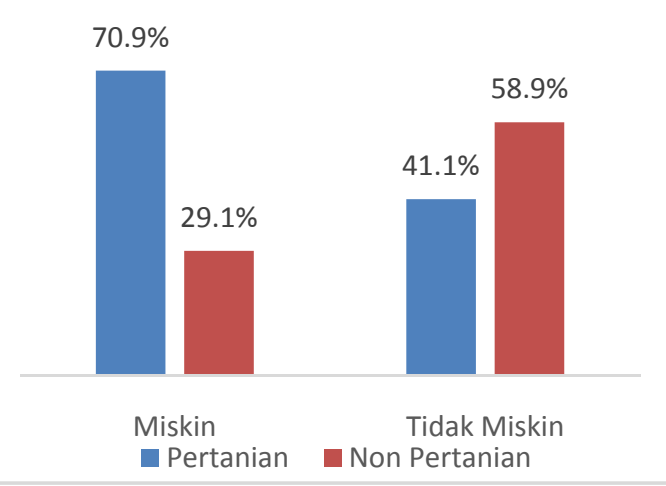

f) Lapangan Pekerjaan

Gambar 1. Karakteristik Penduduk Miskin di Papua Barat

Migrasi life time yang dilakukan oleh penduduk propinsi Papua Barat sebesar 76,79 persen. Penduduk yang melakukan migrasi life time lebih sedikit persentase kemiskinannya dibandingkan dengan penduduk yang tidak melakukan migrasi life time yaitu 78,56 persen. Artinya penduduk yang dari lahir tinggal di Papua Barat lebih banyak yang miskin daripada yang bermigrasi (Gambar 1.c).

\section{Gangguan kesehatan}

Taraf kesehatan dan gizi yang rendah menyebabkan rendahnya daya tahan fisik, daya pikir dan prakarsa. Gangguan kesehatan yang dialami oleh anggota rumah tangga tidak menyebabkan persentase rumah tangga miskin meningkat. Pada gambar 1.d, persetase rumah tangga miskin hanya $16.5 \%$ dibandingkan dengan yang tidak mengalami ganguan kesehatan sebesar 22.4 persen. 
Data Susenas menyebutkan bahwa, tidak ada perbedaan yang signifikan derajat kesehatan penduduk antara orang miskin dan tidak miskin. Penyakit dapat menimpa ke setiap orang tanpa membedakan status ekonominya. Yang membedakan antara penduduk miskin dan tidak miskin adalah cara mengobati penyakit yang diderita. Jika menderita sakit, orang miskin cenderung lebih banyak mengobati sendiri yaitu dengan cara pengobatan tradisional atau membeli obatobatan yang dijual bebas di pasaran.

\section{Pendidikan}

Taraf pendidikan yang rendah mengakibatkan kemampuan pengembangan diri terbatas dan menyebabkan sempitnya lapangan pekerjaan yang dimasuki. Taraf pendidikan yang rendah juga membatasi kemampuan untuk mencari dan memanfaatkan peluang

Kepala keluarga yang pendidikannya SMP dengan status miskin sebesar 23,3 persen lebih banyak dibandingkan dengan penduduk miskin yang berpendidikan SMA keatas, sedangkan penduduk tidak miskin lebih banyak yang berpendidikan SMA keatas.

Tingkat pendidikan di Provinsi Papua Barat pada umumnya masih sangat rendah. Rata-rata lama sekolah penduduk umur 25 tahun ke atas sejak tahun 2016 sampai tahun 2017 tidak mengalami perubahan yang berarti dan baru mencapai 7,15 tahun yang berarti berada tidak jauh dari lulusan sekolah dasar atau rata-rata tersebut masih berada di bawah rata-rata nasional yang mencapai 8,10 tahun (Gambar 1.e). Rata-rata Lama Sekolah (RLS) Provinsi Papua Barat mencapai 7,15 tahun bermakna bahwa rata -rata penduduk Provinsi Papua Barat baru mampu menyelesaikan pendidikan sampai dengan kelas 1 SMP atau putus di kelas 2 SMP (BPS Papua Barat, 2017a dan 2017b).

Faktor yang menyebabkan rendahnya tingkat pendidikan masyarakat, diantaranya: 1) tingginya jumlah anak-anak yang putus sekolah maupun tidak bersekolah karena alasan ekonomi, 2) terbatasnya jumlah anak-anak dari pedesaan yang berhasil masuk sekolah lanjutan menengah ataupun perguruan tinggi karena tidak tersedia di daerahnya.
Rendahnya tingkat pendidikan penduduk di Papua Barat menyebabkan terbatasnya akses ke lapangan kerja. Lapangan kerja yang bisa diperoleh atau tidak ada persyaratan pendidikan, pada umumnya menawarkan upah yang rendah. Hal ini menyebabkan rendahnya tingkat pendapatan yang bisa diperoleh oleh tenaga kerja dengan tingkat pendidikan yang rendah. Rendahnya tingkat pendidikan masyarakat menjadi faktor utama penyebab kemiskinan dan pengangguran di Papua.

\section{Lapangan pekerjaan}

Jenis pekerjaan utama dalam rumah tangga merupakan faktor yang dapat mempengaruhi kemiskinan rumah tangga. Sebagian besar penduduknya tinggal di wilayah pedesaan dan tumpuan kehidupan masyarakat sehari-hari ada di sektor pertanian (BPS Papua Barat, 2016).

Reksosudarmo, dkk (2009) menyatakan bahwa pada tahun 2000 lebih dari 86 persen Penduduk asli Papua tinggal didaerah pedalaman dan terlibat di sektor pertanian. Survei Angkatan Kerja Nasional (SAKERNAS) sampai dengan Agustus Tahun 2013 memberikan gambaran bahwa sektor pertanian masih mendominasi penyerapan tenaga kerja di Papua Barat yaitu 48,17\% dan ini didukung dengan hasil perhitungan Pendapatan Regional Bruto (PDRB) dimana sektor pertanian memberikan share yang cukup besar terhadap PDRB di Papua Barat dan jika dilihat per wilayah maka penduduk miskin terkosentrasi di wilayah perdesaan.

Lapangan pekerjaan penduduk di Propinsi Papua Barat adalah pertanian dan 70,9 persen dari mereka adalah penduduk miskin, sementara kepala rumah tangga yang pekerjaannya non pertanian hanyalah 41,1 persen yang miskin (Gambar 1.f) .

Meskipun persentase penyerapan tenaga kerja di sektor pertanian cukup tinggi, pada kenyataannya sebagian besar penduduk yang tinggal di pedesaan kehidupannya kurang sejahtera dibandingkan penduduk di perkotaan. Pada sektor pertanian tingkat upah minimum yang akan diterima oleh pekerjanya akan lebih rendah dibandingkan pada sektor lain. Walaupun nilai tukar petani (NTP) pada Desember tahun 2016, 
sebesar 100,17, yang berarti petani mengalami surplus, akan tetapi NTP tersebut merupakan gabungan dari 5 subsektor pertanian yaitu tanaman pangan, hortikultura, tanaman perkebunan rakyat, peternakan, dan perikanan. Subsektor perkebunan rakyat dan perikanan memberikan kontribusi yang cukup besar terhadap besarnya NTP tersebut. Walaupun NTP surplus, pada umumnya petani di Papua Barat yang didominasi oleh usahatani tradisional masih memiliki pendapatan yang relatif rendah. Hal ini karena praktek pertanian masih dilakukan secara mulai dari pertanian meramu, ladang berpindah serta sebagian sudah petani ladang menetap dan perkebunan. Kegiatan pertanian yang masih tradisional ini menghasilkan pendapatan yang relatif rendah dan musiman. Petani masih belum secara penuh terlibat pada pasar yang tersedia. Oleh karena petani memiliki keterbatasan dalam memperoleh pendapatan akibat pengetahuannya yang rendah, usahataninya, termasuk peralatan yang masih tradisional, terbatasnya lahan atau pada umumnya lahan pertanian sempit, juga terbatasnya akses ke pembiayaan dan dukungan pemerintah (Wambrauw, 2013).

\section{Tempat tinggal di pedalaman (terisolasi)}

Banyaknya penduduk miskin secara tidak berdaya karena terpencil dan terisolasi sehingga sulit atau tidak dapat terjangkau oleh layanan pendidikan, kesehatan dan gerak kemajuan yang dinikmati oleh masyarakat lainnya. Persentase penduduk miskin di Papua terbanyak berada daerah pedalaman termasuk di kawasan pegunungan, juga perairan, dimana sebagian besar wilayah tersebut masih ditutupi hutan dengan akses transportasi yang sulit. Di provinsi Papua Barat, Pegunungan Arfak merupakan daerah yang letaknya di pegunungan. Sebagai contoh, menurut Ketua Komisi C DPRD Kabupaten Pegunungan Arfak, Origenes Wonggor, letak geografis yang sulit dijangkau serta terbatasnya infrastruktur jalan dan jembatan membuat 95 persen masyarakat di wilayah itu masih hidup di bawah garis kemiskinan (https://www.pasificpos.com/item/ 4520-wonggor-95-persen-masyarakat-pegafberada-di-bawah-garis-kemiskinan). Selain daerah pegunungan masyarakat di daerah pesisir di Papua Barat juga banyak yang sulit untuk dijangkau karena keterbatasan sarana transportasi.

\section{KESIMPULAN}

Kemiskinan adalah sebuah permasalahan yang dialami setiap negara terutama negara berkembang, seperti Indonesia. Faktor yang menyebabkan kemiskinan berbeda-beda baik di tingkat provinsi maupun di tingkat kabupaten/kota. Kemiskinan di Provinsi Papua Barat disebabkan oleh berbagai faktor, antara lain jumlah tanggungan keluarga, migrasi risen dan lifetime, gangguan kesehatan, tingkat pendidikan, lapangan pekerjaan, letak geografis dan lainnya.

Persentasi kemiskinan tertinggi di Provinsi Papua Barat berada di wilayah pedesaan. Walaupun Papua Barat masih merupakan provinsi dengan kemiskinan yang tinggi, akan tetapi tingkat kemiskinan di Provinsi Papua Barat dari tahun 2009 sampai dengan tahun 2016 mengalami penurunan.

Wilayah pedesaan merupakan wilayah dimana penduduk miskin di Provinsi Papua Barat tertinggi berada dan karena pertanian merupakan lapangan pekerjaan bagi penduduk di wilayah pedesaan maka hal ini perlu perhatian pemerintah dalam pengembangan sektor pertanian dan perbaikan infrastruktur jalan.

\section{DAFTAR PUSTAKA}

Badan Pusat Statistik. 2014. Perkembangan Beberapa Indikator Utama Sosial-ekonomi Indonesia. Jakarta

Badan Pusat Statistik. 2018. Perkembangan Beberapa Indikator Utama Sosial-ekonomi Indonesia. Jakarta

Badan Pusat Statistik Provinsi Papua Barat, 2016. Berita Resmi Statistik. Papua Barat: Bidang Statistik Sosial, No. 04/ 01/91/Th. VIII, 2 Januari 2014.

Badan Pusat Statistik Provinsi Papua Barat. 2016. Statistik Nilai Tukar Petani Provinsi Papua Barat.

Badan Pusat Statistik Papua Barat. 2017. Berita Resmi Statistik Januari 2017

Badan Pusat Statistik Papua Barat. 2017. Indeks Pembangunan Manusia (IPM) Provinsi 


\section{Papua Barat}

Badan Pusat Statistik Papua Barat. 2017. Papua Barat dalam Angka Tahun 2017.

Hammar, Robert KR. Dan Julius Herry Saptomo. 2008. Kemiskinan Dalam Dimensi Ekonomi, diakses 8 Pebruari 2014

Kemal, A Stamboel. 2012. Panggilan Keberpihakan. Gramedia Pustaka Utama. Jakarta

Kuncoro,. Mudajrat, 2006. Ekonomi Pembangunan. Penerbit Salemba Empat Jakarta.

Rumbewas, Spener. 2005. Poverty in Three Villages in Papua. A Thesis Submitted in
Partial Fulfilment of the Requirements for the Degree Doctor of Philosophy in Developmeent Studies at Massey University.

Wambrauw Ludia T. 2013. Indigenous Entrepreneurship by Papuan Women in the Informal Agricultural Sector in ManokwariWest Papua Province in Indonesia: A Thesis Submitted in Partial Fulfilment of the Requirements for the Degree of Doctor of Philosophy at Lincoln University.

Widodo, Tri. 2006. Perencanaan Pembangunan Aplikasi Komputer (Era Otonomi Daerah Jogjakarta). UPP STIM YKPN. 